\title{
Architectural Conservation in Rapidly Urbanising Cities: The Case of Dar es Salaam, Tanzania
}

\section{Fabian S. Kigadye}

\section{(2) OpenEdition}

12 Journals

Electronic version

URL: https://journals.openedition.org/eastafrica/342

DOI: $10.4000 /$ eastafrica.342

ISSN: 2790-1076

Publisher

IFRA - Institut Français de Recherche en Afrique

Printed version

Date of publication: 1 September 2014

Number of pages: $29-54$

ISSN: 2071-7245

\section{Electronic reference}

Fabian S. Kigadye, "Architectural Conservation in Rapidly Urbanising Cities: The Case of Dar es Salaam, Tanzania", Les Cahiers d'Afrique de l'Est / The East African Review [Online], 49 | 2014, Online since 07 May 2019, connection on 09 December 2021. URL: http://journals.openedition.org/ eastafrica/342 ; DOI: https://doi.org/10.4000/eastafrica.342 


\title{
Architectural Conservation in Rapidly Urbanising Cities: The Case of Dar es Salaam, Tanzania
}

\author{
Fabian S. Kigadye
}

\begin{abstract}
Dar es Salaam city is changing structurally by replacement of old building with new. Thus, the city is facing challenge on conservation of built heritage due to demolition of historic building and the area surrounding historic monument. Historic building are demolished to pave way for construction of new building for housing and office spaces to meet the free market economy demand. According to the existing legislations, buildings are protected as national monuments by listing individual building, group of buildings or conservation of area. Part of historic city centre of Dar es Salaam was declared as Architectural Conservation area with Government Notice No.498 of September 8th, 1995. The aim was to protect historic and architectural values of the area. Eighteen years (18) after declaration of conservation area, it is observed that there is increasing demolition of historic building and construction of new building which does not match with existing historic townscape and context. It is observed that, designation of a consevation area has been ineffective, because there is weakness in legislations and institutional framework for management of the conservation area. It is recommended that, national authorities should harmonize national policies and legislations and strengthen institutional linkages for heritage conservation and management.
\end{abstract}

\section{Introduction}

Like environmental conservation, conservation of historic towns has been effected by command and control policies and regulations that provide for the protection of designated sites and structures. Most countries have national legislation to "list" or designate cultural heritage resources, ${ }^{2}$ though levels of protection vary greatly (Birabi, 2007). As the field has evolved, it has become clear that, although there may be some inherent value(s) in such places, such approaches must be coupled with integrated strategies for managing the built environment as a whole and with participatory processes that engage communities and stakeholders in decision-making about their heritage. Thus, conservation of historic towns is not simply an end in and of itself, but rather a tool among many to steward cultural resources, to foster a sense of community and identity, to promote sustainability in building and construction, and to improve quality of life.

$1 \mathrm{PhD}$ fellow, Université de Pau et des Pays de l'Adour / Antiquities Division, Ministry of Natural Resources and Tourism. Email: kigadye@yahoo.com

2 Heritage conservation is the management of heritage through research, planning, preservation, maintenance, reuse, protection and/or selected development in order to maintain sustainability, harmony, and the capacity to respond to the dynamics of the age to develop a better quality of life (ICOMOS: 2003). 
Many years passed before the Venice Charter and its agenda of conserving monuments was followed by similar guidelines for urban areas in the 1970s. These were preceded by decades of urban destruction caused by both war and modernizations (Areskough \& Persson, 1999:60). The towns were rebuilt, or redesigned; it became apparent that the town planning principle of the 20th century was quite different from the urban growth patterns. The protection of town therefore became a necessity and the urban environment was promoted from being the monument's context to a valuable milieu in its own right (Ibid). According to Gazzola (1978),

' $(t)$ he assemble of properties that referred to cultural history came to constitute the cultural heritage of a nation. This meant a shift from the criteria related to protection of things of remarkable interest (1931 Athens Charter) to criteria related to conservation of an assemble of things including the single object, the urban environment, and the landscape, which together formed the testimony of culture, of a significant evolutions, of an event. All this was with reference even to modest works that has acquired cultural significance over time.' (Gazola 1978: 242).

This same policy concept was clearly expressed in the general principle of the 1976 Recommendation of UNESCO concerning the Safeguarding and Contemporary Role of Historic Area. The recommendation stipulates that:

Every historic area and its surroundings should be considered in their totality as a coherent whole, whose balance and specific nature depend on the fusion of the parts of which it is composed and which include human activities as much as the buildings, the spatial organization and the surroundings. All valid elements, including significance in relation to the whole must not be disregarded (art.3)

The ICOMOS Charter for the Conservation of Historic Town and Urban areas defines the components that create the characters of a historic town. These components consist of urban patterns such as lots and streets, and the relationship between buildings and green and open spaces. Moreover, individual buildings size, scale, style, colors, decorations and constructions materials - not only exterior but also interior - is important. In a wider context also, the surrounding setting and the functions of the town constitute its essence. The largest difference between the principle of conserving monuments and areas seems clear, conserving monuments aims at preservation while conservation of urban areas aims at and adaptation to contemporary life (Areskough and Person 1999:60). 
In a world of rapid change, visible and tangible evidence of the past may also be valued for the sense of place and continuity it conveys. The presence of historic building is a testimony to the passage of time in a particular locality. Ashworth and Tunbridge (1990), quoting Lynch (1960), argue that:

'place familiarity is valuable in maintaining the individual psychological stability and an over-abrupt change in the physical environment must be modified by conservational policies, so as that the excitement of the future should be anchored in the security of the past.'

The aesthetic appeal of an historic place may result from the combination or juxtaposition of many buildings rather than the individual merits of any particular building. Most cities are made up of buildings from a range of period in a variety of style and idioms. Thus, the past may be valued because of its juxtaposition with the present. In particular, the older building provides potent contracts to the interminable sterility and monotony of much of modernist architecture. Such diversity is usually viewed positively. Mumford (1938), cited in Tiesdell (1996:13), said that 'by the diversity of its time structures, the city in the past escapes the tyranny of a single present, and the monotony of a future that consists in repeating only a beat heard in the past.'

\section{New Building in Historic Towns}

The issue of new building in historic town was recognized by the ICOMOS, and the concern for historic cities were principally assumed by the International Committee on Historic Cities and Village (CIVVIH) that has since collaborated in a number of such declarations. As a result of meeting in Bruges in 1975, the principles governing the rehabilitation of a historic town recognized that preservation necessitated the adaptation of a historic town to the requirements of contemporary life, but that this should be done without destroying its existing fabric, structure, or historical evidence. The principles also accepted the possibility of new buildings in historic setting; it declared that respect for authenticity implied the integration of modern architecture in old town.

This meant that importance is given to functional continuity as well as maintenance of historic fabric. Following the same lines of thought, the 1987 ICOMOS Charter for the conservation of Historic Towns and Urban areas declared (article 10) that: 'when it is necessary to construct new building or adopt existing ones, the existing spatial layout should 
be respected, especially in terms of scale and lot size. The introduction of contemporary elements in harmony with the surroundings should not be discouraged since such features can contribute to the enrichment of an area.' The European Charter for Architectural Heritage (1975) emphasized the need to guarantee a harmonious social balance in historic cities. The Charter also defined the concept of 'integrated conservation', and referring to new buildings, it declared:

It should be noted that integrated conservation does not rule out the introduction of modern architecture into areas containing old buildings provided that the existing context, proportions, forms, sizes and scale are fully respected and traditional materials are used.

The same concepts were promoted in the Convention for the Protection of the Architectural Heritage of Europe (Granada 1985), which emphasized that integrated conservation policies should 'include the protection of architectural heritage as an essential town and country planning objective and ensure that this requirements is taken into account at all stages both in the drawing up of development plans and in the procedures for authorizing work.'

However, in this context, the Management Guidelines for World Cultural Heritage Sites, published by ICCROM, emphasize that the primary objective of Conservation Planning is the conservation of existing historic fabric: 'The building of new structure should not be an excuse for demolishing old one. New construction may, however, be necessary to re-establish functional and architectural continuity, and in case where empty lots might be hazardous to or further decay surrounding buildings.'

It is possible to identify design criteria related to architectural requirements, but it is equally essential to consider the historical integrity of an historic settlement. This demands identification of the elements that together define the fabric and infrastructure of a city, their mutual connections, and the relationship within the cultural landscape of which the settlement is part. The policies regarding the construction of new buildings should be based on the understanding of these complex relationships (Warren, 1998).

According to David Throsby (2007: 22), 'historic building is an asset that has financial value as capital (it could be sold off as real estate for commercial developments), and it also has financial value in terms of the flow of services it provides (estimated, for example by the rental value of the office space).' These aspects of the buildings value could be called its economic value as a piece of purely physical capital. As such, this 
economic value could be provided by any building. But this is not just "ordinary" building; its distinguished feature is that it also has cultural value, delivering from the cultural significance which is essential to its qualification as cultural heritage. Like its economic value, the building's cultural value is seen both in its worth as capital (the accumulated sense of cultural significance embodied in the building's very fabric) and in terms of the flow of service it provides (its historic or aesthetic qualities that are enjoyed every day by workers, visitors and passer-by) (Ibid).

Reconciling conservation and development is a prerequisite for achieving improvement of the quality of life in environmentally and culturally sensitive places. By shifting the focus on perception and valuations, conservation becomes a dynamic process involving public participation, dialogue, and consensus, and ultimately better stewardship (Matero, 2011).

\section{Historical Overview of the City of Dar es Salaam}

Dar es Salaam is a coast city in the United Republic of Tanzania situated along the Indian Ocean. It covers an area of 1,393 square kilometer with an estimated population of 4.5 million people. The city is located between latitudes 6.36 degrees and 7.0 degrees to the south of the equator and longitudes 39.0 and 33.33 to the East of Greenwich. Dar es Salaam is one among many cities in the Sub-Saharan Africa that are experiencing rapid urbanizations. The city is relatively a new city that emerged during the German and British colonization of Tanganyika. ${ }^{3}$ The history of Dar es Salaam commenced with its establishment in the 1860s by Sultan Majid and its growth through Arab, German and British colonial periods and the post colonial period. Likewise, the architectural evolutions of the city centre stretches across: Arab, German British and postcolonial eras (Moshi, 2009:27). The city is well endowed with buildings erected during the first fifty years of its existence. The Swahili houses and colonial buildings added to the beautiful architecture of Indians buildings and early post-independence structure. Historical buildings have great potential for citizens to identify with their city, for cultural tourism and, not least, for the real estate market. The individuality and variety of its architecture are a major contribution to the beauty and unique character of the city.

3 Tanganyika is the former name for Tanzania mainland. In 1964, the Republic of Tanganyika and the Republic of Zanzibar united and formed a country known as the United Republic of Tanzania. 
When German took over Tanganyika in 1891, Dar es Salaam was just a small settlement with a population of about 4,000 inhabitants (Sutton, 1970; Kombe, 1995:10; Lupala 2002:31). In the same year, the Germans shifted the capital from Bagamoyo to Dar es Salaam. Due to increased trade and importance, because of the establishment of port facilities and administrative activities in the city, more migrants were attracted and the populations increased to 10,000 inhabitants by the year 1894. Six years later, the population reached 20,000. Population's growth slowed down over the war periods (World War I and II) and a steady increase was notable after the 1950s. A faster growth was noted after independence mainly because of the abandonment of the policies that inhibited Africans from migrating to towns. By 1968, the populations were increased to 69,277. The populations of Dar es Salaam reached 782,000 by 1978 (figure 4.1). While in 1992, estimated populations for the city was pegged at 1,550,000 inhabitants and in the year 2002 the city had estimated populations 2,497,940.

Whilst the city spatial expansion has been growing at an average rate of $7.2 \%$, the annual average growth rates of populations for inter censual period has been also high. For example, the average annual growth rate between 1948 and 1957 was established to be $7.1 \%$. This figure increased to $7.8 \%$ between 1957 and 1967 and further to 9.7 between 1967 to 1978 (Lupala, 2002:31). The growth rate slowed down to $4.8 \%$ between 1978 to 1988 , but sharply rose to $9.1 \%$ as estimated between 1988 and 1995 (Strategic Plan, 1998:13-14). Recent estimates show a decreased rate to 3.1\% for the period between 1995 and 2001 (Lupala, 2001 and 2002:31). These fluctuating trends in growth rates illustrate an observation that, while rural urban migration has been pointed out as one of the major factors of rapid urbanization in Sub Saharan cities, natural populations increase has also played a significant role especially in the decades of 1980s and 1990s (Lupala, 2002:31).

Based on the statistics above, Kironde (2000) said that '(a)fter 1948, and particularly since independence, direct control of direction of Dar es Salaam's development has been less easy on account of the sheer number of people being added to the city per annum, as well as the inappropriateness of the tools in hand to deal with this growth.'

The City has three Municipal Councils, ${ }^{4}$ namely Ilala, Kinondoni and Temeke. These Municipalities form three districts of Dar es Salaam Region. Dar es Salaam was declared a township in 1920 and in 1949 it was upgraded to municipality. When Tanganyika became independent in 1961, Dar es Salaam was elevated to a city status.

4 In 1999, three district of Dar es Salaam were named as municipalities. 


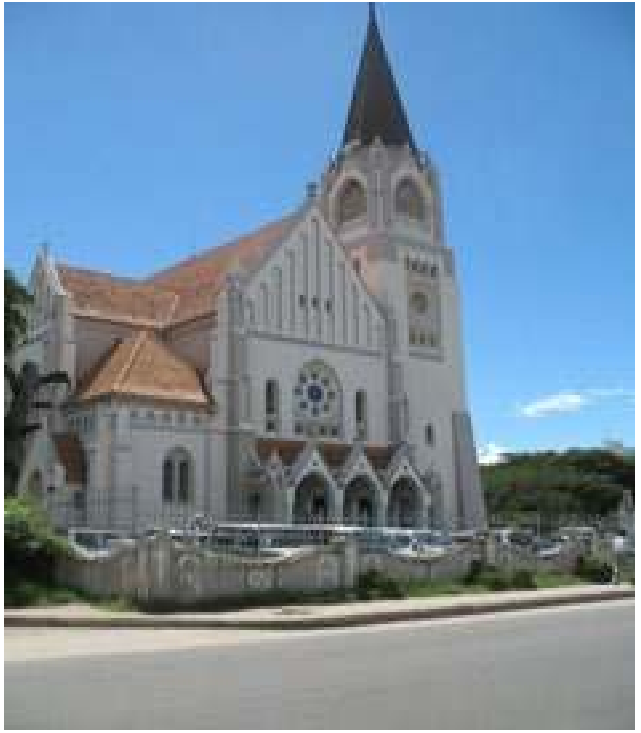

St Joseph Church

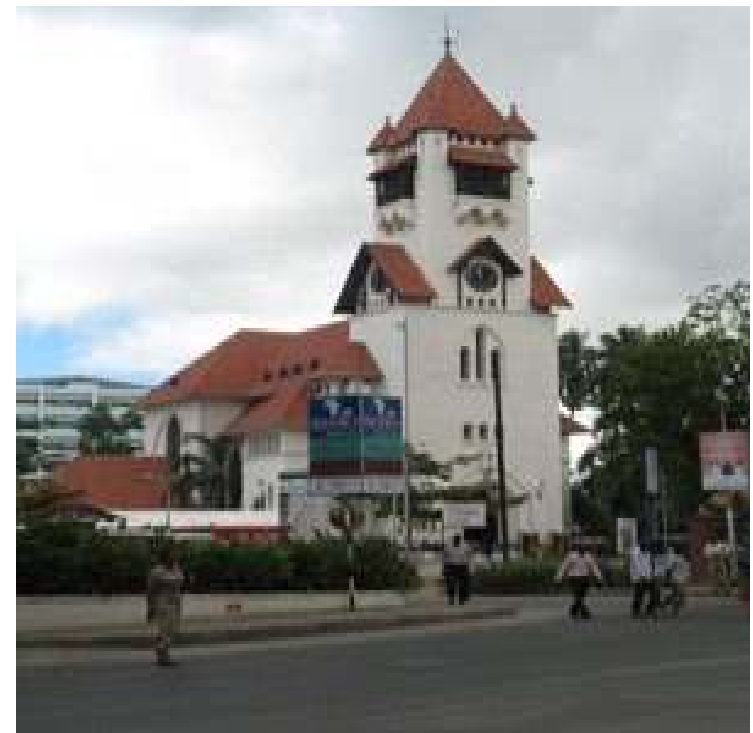

Azania Front, Lutheran Church

These building depict the German gothic style building in Dar es Salaam of the 19th century. Evidence of the Greco-Roman influence of architecture.

\section{Architectural Conservation Initiatives in Dar es Salaam}

Conservation of built heritage in Dar es Salaam was initiated by the Department of Antiquities in the year 1973 when the Minister responsible for Antiquities appointed an ad-hoc committee to study and recommend on the desirability of conserving buildings of historical and architectural significance. Following the recommendation of the Committee, the Minister submitted a paper to the Cabinet and the Cabinet did not agree to all the suggested areas and buildings. It only selected a few building which were to be protected as monuments. By that time, provisions for legal protection on the cultural heritage was based on the principle of listing and scheduling of individual structure or buildings which were deemed of historic or architectural significance as monuments. It was considered inadequate to offer the required legal protection to the whole area of the city. Changing the legal regime for the protection and preservation of cultural heritage resources was given priority in the implementation of the policy decision for the protection of historic centre. This was achieved in 1979, when the Antiquities (Amendment) Act was enacted by Parliament. This, among other things, enabled the Minister responsible for "Antiquities", in consultation with the Minister responsible for "Lands," to declare a conservation area or a site which, in his opinion, was a valuable national heritage for its aesthetic value 
or contains a homogenous group of Monuments or contains, structure or other forms of human settlement which in his opinion are valuable national heritage for their historic, architectural, social and cultural value.

The battle to save the Old Boma building ${ }^{5}$ from demolition in 1979 was important in bringing public attention to the values of historic buildings in the city. On this occasion, the Division of Antiquities was supported by teachers, architects, and even those who had previously been responsible for the demolition of the former New Africa Hotel building. The Division of Antiquities, however, maintained that instead of protecting these buildings one by one, aerial protection should be provided in order to preserve them in their context. However, after long discussions with the central government, building owners and the city council in the year 1995, the Division of Antiquities managed to declare 26 historic building, 5 Monuments and 1 Architectural Conservation Area. The listed historic buildings are still intact and in use. These buildings were declared national monuments with government notice No 498 of September 8th, 1995.

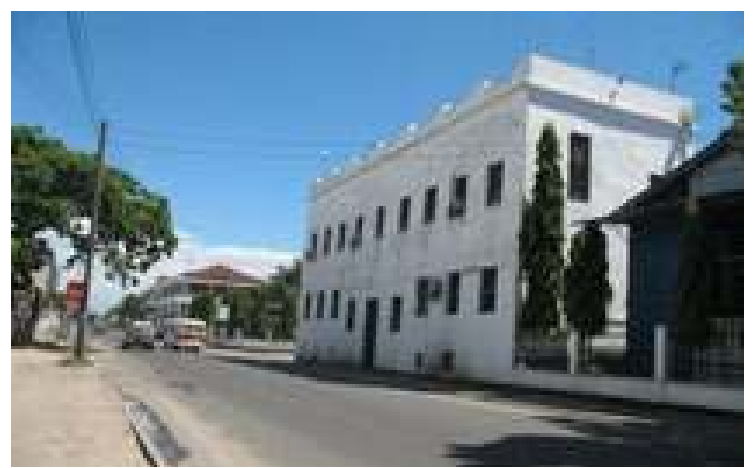

The Old Boma Building on Sokoine Drive

\section{The Architectural Conservation Area: A Case Study}

The Architectural Conservation Area of Dar es Salaam is a built heritage site from the late 19th century which occupies the most prime site in the city centre within Ilala Municipality. It exhibits unique cultural and architectural landscape: this heritage values has survived for over 100 years. It was established by the German colonial administration as the administrative and political centre of Dar es Salaam and expanded and consolidated during the British colonial administration. It contains buildings and cultural landscape

5 The Old Boma Building was constructed in the 1860s during the Sultan Majid. 
which are of great architectural, historical and aesthetic values early 19th and 20th century. The planning and designing of this area inform of a large botanical garden that is unique in the context of urban planning and design. It is an outstanding example of architectural ensemble and landscape which illustrates significant stage in the city development. It is because of its historical and architectural value that the Division of Antiquities, in collaboration with the Ministry of Land and Housing Development, declared this part of the city an Architectural Conservation Area with a Government Notice No.498 of September 8th, 1995. The area concerned covers the area between Ocean Road, Chimara Road, Shaaban Robert Street, Sokoine Drive, Azikiwe Street and Kivukoni Front. The total size of the Conservation Area is $0.4642 \mathrm{~km} 2$ (URT, 2004).

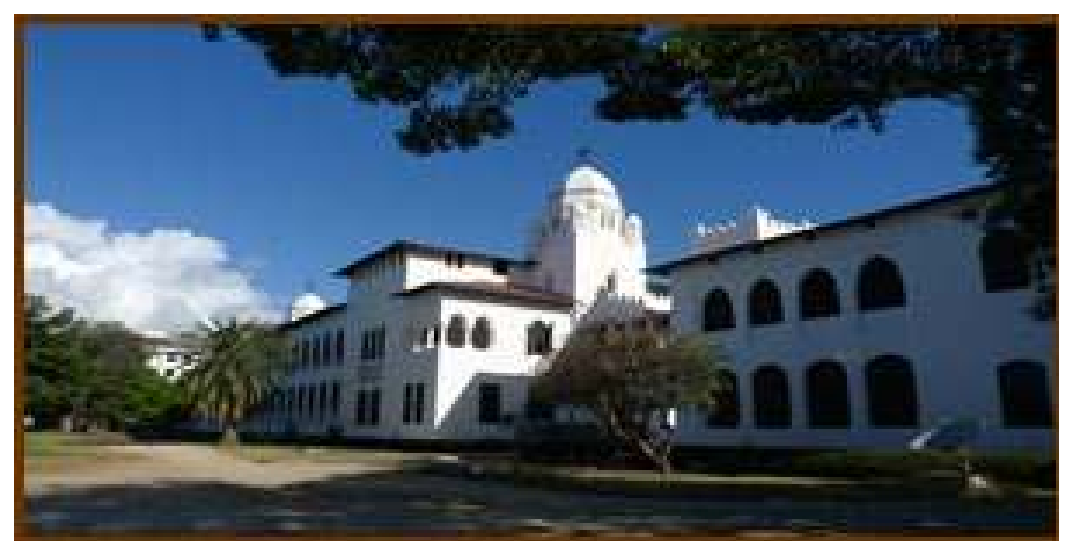

The Ocean Road Hospital in the Conservation Area, German Built Structure

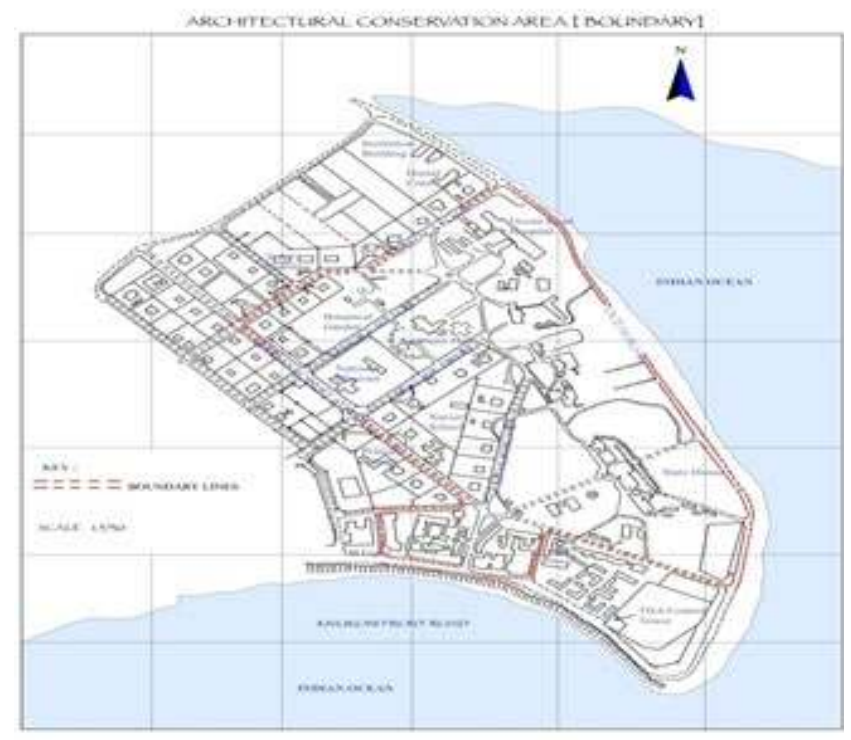

Source: Author, 2010 


\section{State of Conservation in the City}

The historic city centre is facing challenge on conservation of built heritage due to demolition of historic buildings and the area surrounding historic monuments resulting from the booming of construction industry in the city centre. Ambitious rebuilding programs and upgrading of outdated infrastructures are conflicting with retention of a unique sense of place, as Vines (2005) observed, stating that '(d)emolition of traditional streetscapes removes a community's to its own special past' (Vines, 2005:1). This process in not reversible-once gone, the familiar and intimately scaled locales cannot be reinstated, and bland, modern, sanitized edifices obliterate the patina and unique qualities of the humble historic townscape.

Moreover, according to Matero (2011), 'unlike the case of natural resources, sustainability for the built environment differs in that historic resources cannot be physically regenerated, only retained, modified or lost.' About the continuous trend of demolition of historic buildings in Dar es Salaam, Moon notes that " $(t)$ here appeared to be no coordination within the Antiquities Division, the authority responsible for heritage matters. In the city as a whole, in fact, the limited Antiquities legislation that existed was routinely ignored". Stressing on the issue of management of architectural conservation area, Warren et al (1998:75) reminds that " $(\mathrm{t})$ here is no point in designating an area for its special interest and then allowing its character to be damaged by destroying buildings or other features that make it special, or by allowing new development that is out of place, scale or context with the area."

The demolition of historic building is against the 1972 UNESCO Convention for the Protection of Natural and Cultural Heritage. The symposium took place in Vienna Austria 2005 and came up with a Memorandum on World Heritage and Contemporary ArchitectureManaging the Historic Urban Landscape as an important outcome of the meeting. The memorandum stresses that " $(t)$ he central challenge of contemporary architecture in the historic urban landscape is to respond to development dynamics in order to facilitate socio-economic changes and growth, on the other hand, while simultaneously respecting the inherited townscape and its landscape setting on the other (UNESCO 2007:95). It also emphasizes the importance of taking into careful consideration the urban context and continuity in planning new development, against 'iconic' architecture based on design models not related to the specific tradition of a place. 
Therefore, the designation of Dar es Salaam City center as an Architectural Conservation Area by the mentioned regulations and allowing the developments that can be seen is in complete contradiction with, and is a reflection of, weakness of conservation practice carried out by the responsible authorities. ${ }^{6}$

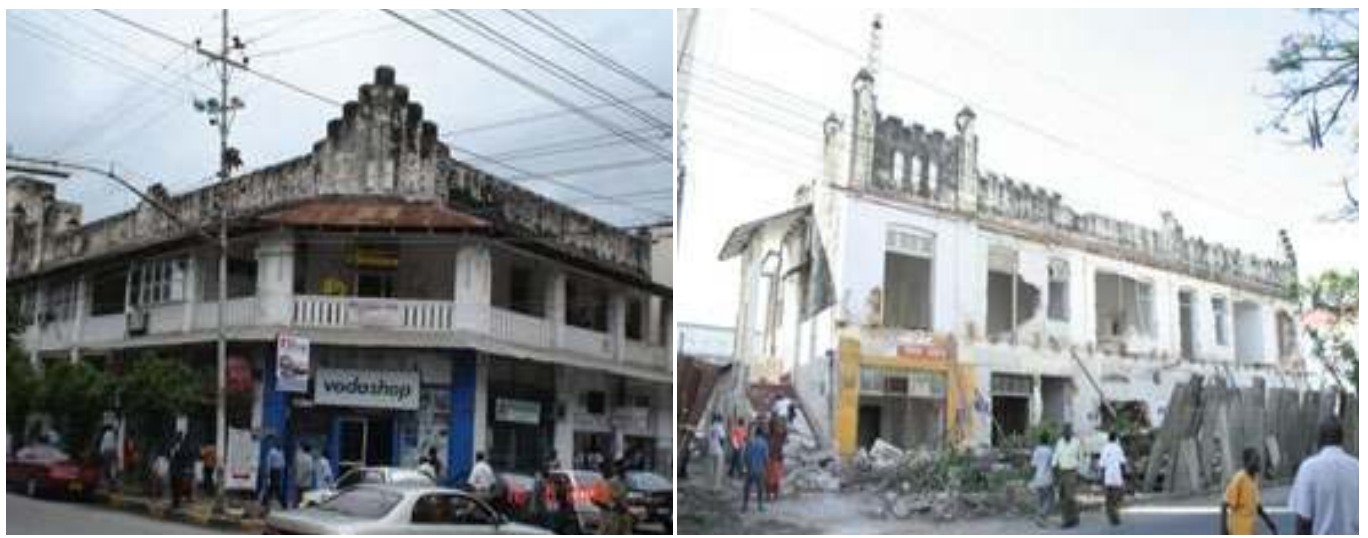

Above: the Salamander building before and during demolition works (the public was against the demolition of this building).

\section{Regulatory Frameworks for Conservation of Architectural Heritage}

The Antiquities Division is a Government institutions responsible for conservation of cultural heritage resources in the country. The Antiquities Act enacted by the independent government in 1964 and amended in 1979 to replace the Colonial Monuments ${ }^{7}$ (Preservation) Ordinance promulgated in 1937, is the basic legislation for the protection and preservation of the country cultural built heritage. Conservation of group of historic buildings was archived in 1979 when the Antiquities (Amendment) Act was enacted by Parliament.

Declaration and management of Conservation Area is also stipulated in the Urban Planning Act of 2007. The Act section 58 gives mandate to the Local Planning Authority to designated conservation areas. The Act says that '( $\mathrm{t}$ )he planning authority ${ }^{8}$ may compile a list of areas, buildings, or groups of buildings of special architectural or historic interest

6 See also Fielden (2004: 261) who reminds that "(i)t is essential that consideration of the values in cultural property should be assessed objectively and fairly. There is always a danger that the conservation program will only reflect the bureaucratic objectives of the government department that is responsible."

7 The issues of 'national monuments' is often loaded with political values, and can be conceived as a question of national pride. Such values can provoke reconstruction and stylistic restoration of desired features of monument, and the elimination and destruction of others contrary to political goals.

8 The Planning Authority is defined by the Urban Planning No.8 Act of 2007 section 7 as "Every city council, municipal council, town council and township authority shall each become a planning authority in respect of its area of jurisdiction". 
and may amend any list so compiled such areas may include Buildings, Artifacts, Group of buildings, Areas of unique biodiversity and rare species of trees and special trees' (Urban Planning Act 2007: 328).

The Dar es Salaam Master Plan (DMP) of 1979 recognizes the importance of architectural conservation. The Master Plan stresses that " $(t)$ hese areas are of significant importance as the buildings and the general character of the area are excellent example of the city's heritage. The existing structure should be retained and, where necessary improvements and restorations undertaken, new structures associated with the existing facilities will be permitted. They shall be limited to three storeys in height and maintaining the character of the existing structure and the surrounding area". However, in terms of management of architectural conservation area, DMP of 1979 management policy article 1 (v) says that '(i)t shall be the policy of the city council to encourage the preservation of properties of historic, architectural or archeological interest. Guidance in this area should be obtained from the Director of Antiquities"

\section{Research Methodology}

This study is based on the survey conducted at the inner city of Dar es Salaam, an area under pressure for redevelopment. To gather useful information on important historic buildings, this study employed interpretative historical research based on literature and case-study approach. Much effort was directed to a comprehensive review of the existing literature, on-site examination of the properties, and photographic, mapping and documentation. A structured questionnaire was also used.

\section{Findings and Analysis}

A number of aspects were looked into, notably legal and institutional frameworks for cultural heritage, development and management plans, public awareness, stakeholders and community participation and the administration structure framework. 


\section{a. Legal and Administrative Systems}

The study has revealed that the legal and administrative system of cultural heritage in Tanzania is linked to the history of the country. The colonial period has left its marks on the legal systems, but even more on the concepts of protection and identification of cultural heritage. The architectural conservation areas under study portray heritage built during colonial times. The existing legal and administrative systems favor the concept of monumentalism and neglect other types of heritage such as historic landscapes or vernacular architecture. It takes also very little or no cognizance of associated intangible and spiritual values. It is observed that the Division of Antiquities has played a more active role compared to Local Government Authorities conservation of the built heritage, but lacked the capacity to link conservation to public policies to mitigate the impact of the economic development. It enlarged the scope of its policies to include built heritage conservation but restricted the action to the narrow track of preservation control on listed monuments. By doing so, it lost the possibility for a future alliance with the owners of heritage properties and local government authorities.

As pointed earlier, current administrative frameworks are derived from systems imposed during the colonial period. The study reveals that, in the Western world, most heritage conservation activities are the responsibility of municipal and county authorities; the central state plays only a supervisory role in policies enacted and follow-ups. But in Tanzania the administration of heritage is vested in the centralized national government administrations. Usually, centralized administration systems make it difficult for heritage management institutions to be responsible for the needs of the communities and stakeholders.

\section{b. Conservation and Management Plan}

The study has revealed that there is not any Conservation Plan or management plan for individual building or for the architectural conservation area. The only document that exists for conservation and management of built heritage in Dar es Salaam is the Master Plan of 1979 and the Dar es Salaam Central Area Redevelopment Plan of 2002. These documents were prepared by the Ministry of Lands, Housing and Human Settlement Development (MLHHSD) to be used by the Dar es Salaam City Council (DCC). The DMP (1979) recognizes the importance of conserving the built heritage. The Plan defined 
heritage area as "areas of significance as the buildings and the general character of the area are excellent example of the city's heritage". The Master Plan guides that existing structure should be retained and, where necessary improvements and restorations undertaken. New structures associated with the existing facilities will be permitted but limited to three storeys in height and maintaining the characters of the existing structure and surrounding areas (DSMP 1979: 91).

The study has also found that the plan did not zone the building or the conservation areas; therefore it was a general proposal. Tamla (1997:123) expressed his concern that the Master Plans include development conditions which are too general to ensure strict and systematic inventory of new developments. For example there are no dictated development conditions and guidelines. The Master Plan emphasizes only about 8 characters in general but no information about facades, frontage, color, massing or walling materials. Moreover, this Plan is outdated, because it was supposed to be revised in every five years of operations, but it has never been revised since 1979, and it was supposed to operate for 20 only (from 1979-1999). ${ }^{9}$

In order to cover the vacuum of an adequate Master Plan, the MLHHSD in collaboration with the DCC prepared the Redevelopment Plan for Dar es Salaam Central Area in the year 2002. This plan was due for three years (2002-2005). It was prepared because of the increasing pressure for the city centre business space that has gained momentum recently hence prompted preparation of the Redevelopment Plan. It was noted that, at present, the development activities are taking place on piecemeal basis with high-rise structures gradually replacing the single and double storey structures without regard to consequential infrastructure and service requirements. The Plan recognized the presence of architectural heritage and a need to preserve the rich history of Dar es Salaam city centre through conservation of buildings and other features of architectural and cultural significance. Yet it zoned the area with historic building to be built with building height from 6 up to 10 storeys, or above 10. Within the architectural conservation area the plan zoned for building with height from 3 to 6 storeys. The existing historic buildings have 1 to 2 storeys.

In an interview with the Town Planner of Ilala Municipal, the latter said that " $(t)$ he Central Area Redevelopment Plan is outdated, because it was prepared to control development for three years and after three years it was supposed to revised". Currently,

9 In 2010/2011 the Government through the Ministry of Land, Housing and Human Settlement Development started to prepare a New Master Plan for the City. To date it is not yet finished. 
physical development taking place in the city is not guided by any document. He added that "conservation of historic building in the city centre is very difficult because every developer want to invest in the city centre because of the availability of social services and infrastructure as well as proximity to other services." The Town Planner also expressed concerns that the local government is the implementing agency of the central government policies, and that conservation of built heritage in urban areas is not yet a government priority. "There is no any budget set for conservation activities at local government level," he went further, suggesting that, since conservation for built heritage is within the Ministry of Natural Resources and Tourism (MNRT) ${ }^{10}$, the Division of Antiquities (DoA) should give funds for conservation of heritage to LGA's as they are doing for forestry and wildlife.

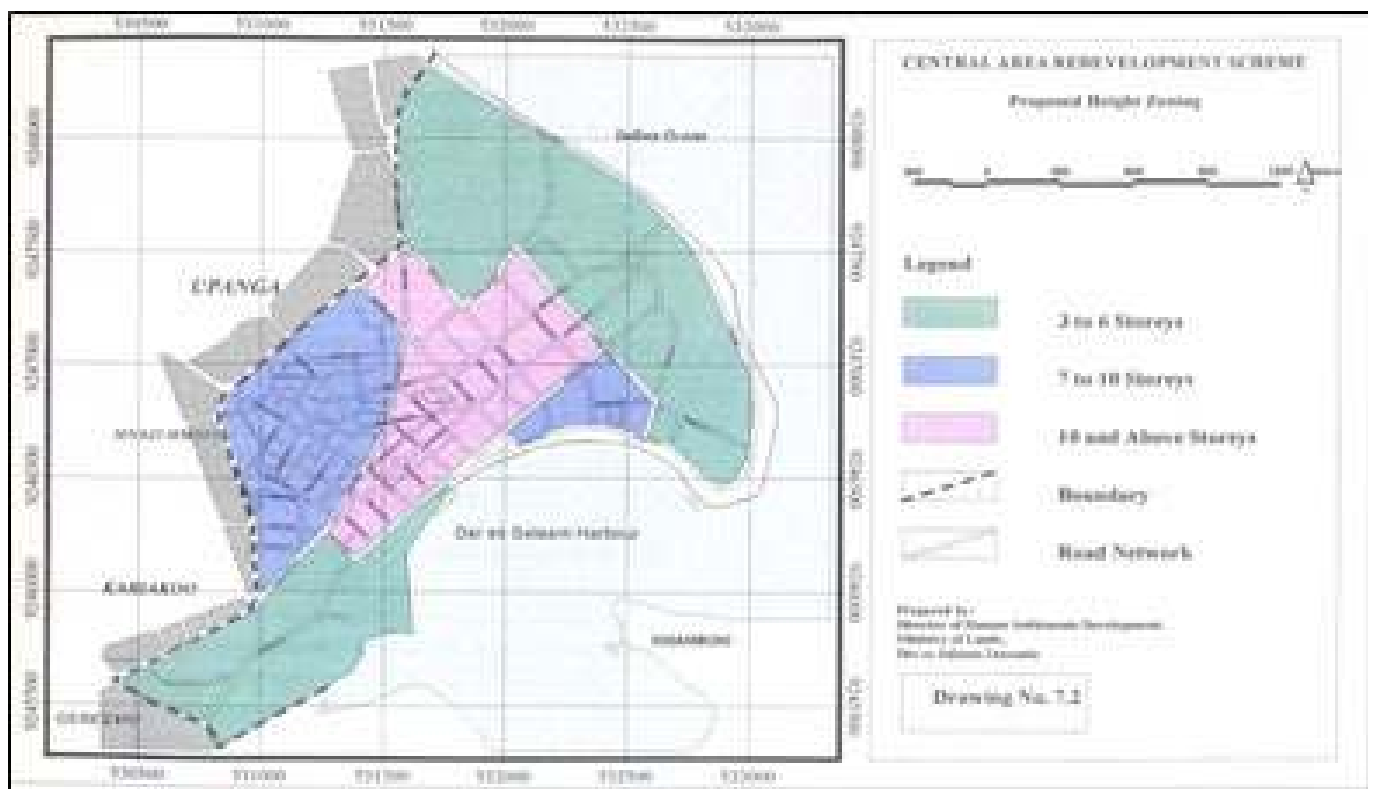

Map No 2. Zoning of Building Height in the City

\section{c. Lack of Appropriate Institutional Frameworks}

There is overlapping jurisdiction between the Division of Antiquities and the Ilala Municipal Council when dealing with any development within the conservation area. The Municipal Council expects their laws to carry more weight in the planning process than the Antiquities Act of 1964. For example, the City Planner said in an interview that the DCC is

10 The Ministry of Natural Resources and Tourism usually gives LGA's funds for conservation of forestry and wildlife in their area of jurisdictions. 
in overall in charge for managements and development in the city. Therefore, the Division of Antiquities should first ask the DCC and get approval for any Conservation Projects within the city. ${ }^{1}$ At present, the only solution at hand is to encourage communication between institutions, since until the laws are revised, they offer little conciliation.

\section{d. Public Awareness and Stakeholder Participation}

The study noted that owners were not well informed of the legal, technical and professional requirements for the conservation of the buildings which they own. Besides that, owners were confused on the role of the various government agencies, especially that of the Division of Antiquities and the DCC. They did not understand their role and responsibilities in the conservation of the buildings which they own. However, some owners expressed their willingness, with proper education, sensitization and involvement to fully participate in the conservation process including financial contributions in rehabilitating their building according to the existing regulations. One good example is the field interview with the manager for the Southern Sun Hotel who said that his hotel was located within the Conservation Area, and for this reason, they should have a role to play in conservation. They are also financing the upkeep of the botanical garden which is one of the key features of the Conservation Area. Based on the above arguments, a conservation policy to be successful, it needs to involve all those responsible, from the policy formulators and the implementing agencies to the users. The Head of the Conservation Section in Division of Antiquities said during an interview that 'the Division has a new policy which was approved in 2008 (and) has taken on board stakeholders and community involvement in conservation of the built heritage'.

\section{e. Administrative Framework}

The legal and administrative regime for the management of the conservation and development of the Dar es Salaam Architectural Conservation area is in place. The Antiquities Act of 1964 as amended by the Antiquities Act of 1979 is the principal legal instrument for the protection and preservation of the historic centre. The Antiquities Division of the Ministry of Natural Resources and Tourism is the central government lead

1 The Antiquities Act requires the Minister responsible for Antiquities to consult the Minister responsible for Lands on issues pertaining to conservation. 
agency for the conservation of the built heritage. Ilala Municipal council is the overall planning and development authority in architectural conservation area. This legal and administrative regime is an opportunity not only for the conservation and development of the conservation area but in the implementation of the Plan. However, there are constraints and issues which need to be addressed and resolved.

- Boundaries: The boundaries of the Conservation Area have not been surveyed, mapped with beacons and a Registered Plan deposited with the Commissioner for Lands. The Plan used as the basis for the declaration of the Conservation Area is not included in the Dar es Salaam Central Area Redevelopment Plan of 2002. The boundaries of the Conservation Area are not clearly marked and have been an issue of dispute.

- Institutional Ownership Problems: The Ministry, when deciding to declare an area a Conservation Area, is legally required to do so in consultation with the Ministries responsible for Land. The sense of these consultation requirements is to ensure the support and agreement of the Ministry responsible for Land and thus giving the area declared to be a conservation area a special status whose main land use is the conservation of heritage resources therein. The Architectural Conservation Area is legally managed and controlled by three institutions: the Ministry responsible for Land, the Ministry responsible for Cultural Heritage and the Ministry responsible for Local Government authorities. Both have laws and regulations which safeguard the priorities of their institutions, but these institutions are always in conflict of interest due to the fact that each of them tends to defend its interests in either development or management issues.

\section{Conclusion}

Heritage management demands reconciling interests of the stakeholders. For effective management of the built heritage there is a need to address the competing interests of different stakeholders. It has been revealed that development and conservation are two faces of the same coin. There cannot be conservation without local development because it is an activity that needs the use of social resources that cannot generate financial benefits in the short term. The impact of development on the conservation of the urban built heritage is partially determined by the urban management process and institutional framework. However, there are impacts that are linked to structural development transformation that directly related to the weakness of the style of urban governance and urban management in Dar es Salaam. 


\section{Bibliography}

ArchiAfrika Newsletter. “Conservation Special Edition.” May 2009.

Batilda, Burian and Alphonce T. Kyariga, Sustainable Development in an Urban Tanzanian Context. Unpublished Paper, Dar es Salaam, not dated.

Birabi, Allan K. International Urban Conservation Charters: Catalytic or Passive Tools of Urban Conservation Practices Among Developing Countries. Kampala: Makerere University, 2007.

Bixter, A. Journal of Architectural Conservation no. 2 (2001).

Casson, W.T. "Architectural Notes on Dar es Salaam Tanzania." Notes and Records 71 (1970): 181-184.

CRATerre-ENSAG/Convention. Cultural Heritage and Local Development, FranceUNESCO. 2006.

DCC. Strategic Urban Development Plan for the City of Dar es Salaam, Volume I. Dar es Salaam, 2005.

English Heritage. Conservation Principles Policies and Guidance. The sustainable Management of the Historic Environment. London: UK, 2008.

Fielden, Bernard. Conservation of Historic Buildings. London: Butterworth and Co. (Publishers) Ltd, 1982.

Gillman, Clement. "Dar es Salaam, 1860-1940: A Story of Growth and Change." Tanganyika Notes and Records 20 (1945): 2.

Helsing, C. et al. The Central Caravan Route Tanzania. Sweden: Lund Institute of Technology, 2004.

ICCROM. Conservation Studies No.5. Legal Frameworks for the Protection of Immovable Cultural Heritage in Africa. Rome, Italy: ICCROM.

ICOMOS. Heritage at Risk. ICOMOS World Report 2001/2002 on Monuments and Sites in Danger. München, Germany: K.G. Saur, 2002.

Isaak, C., A Catalogue for the Protected Buildings in Dar es Salaam, Tanzania. Dar es Salaam: DCC, 2009.

Kamamba, Donatius. Conservation of Dar es Salaam. Great Britain: Institute of Advanced Architectural Studies, University of York, 1990. 
Kironde, J. M. The Regulatory Framework, Unplanned Development and Urban Poverty: Findings from Dar es Salaam. Dar es Salaam: Tanzania, 2006

Kothari, C.R. Research Methodology. New Dehli: New Age International Limited Publishers, 2007.

Kyessi, Alphonse G. Community Participation in Urban Infrastructure Provision. Dortmund: Spring Centre, 2002.

MLHSD. Dar es Salaam Central Area Redevelopment Plan. Dar es Salaam: The Human Settlements Division, Ministry of Lands Housing and Human Settlement Development. 2002

MLHSD. Government Notices, Orders, Technical Instructions and Circulars Commonly Referred to in Pursuance of Human Settlements Development. Dar es Salaam: The Human Settlements Division, 1999.

MLHSD. National Human Development Policy, Government Printer. Dar es Salaam: Tanzania, 2000.

Osborne, J. M. “The Berlin Mission.” Tanganyika Notes and Records 54 (1960): 64-68.

Patton, M. How to use Qualitative Methods in Evaluation. London: SAGE Publication, 1987.

Rodwell, Dennis. Conservation and Development in a Historic City. UK: Donhead Publishing, 2004.

Sheuya, Shaaban A. Housing Transformations and Urban Livelihoods in Informal Settlements. Spring Centre, University of Dortmund Germany, 2004.

Sutton, John E. "Dar es Salaam: A Sketch of a Hundred Years." Tanzania Notes and Records 71 (1970): 1-19.

Sutton, John E. "Dar es Salaam City, Port and Region." Tanzania Notes and Records, 71 (1970).

Sykes, Laura and Uma Waide. Dar es Salaam: A Dozen Drives around the City. Dar es Salaam: Mkuki na Nyota Publishers, 1997.

Tamla, S. Conservation of Historical Towns along East African Coast (Tanzania), Unpublished PGD Dissertation, UCLAS, Dar es Salaam, 1997

Tiesdell, Steve, Taner Oc and Tim Heath. Revitalizing Historic Urban Quarters. Great Britain: MPG Books, 1996. 
Numéro Varia

UNESCO. Challenges for the Millennium World Heritage. Paris, France: WHC, 2007.

URT. Antiquities Legislation of 1964 with its amendment of 1979 No.10. Dar es Salaam.

URT. National Environmental Policy. Dar es Salaam: Vice President's Office 1997.

URT. Urban Planning Act of 2007. Dar es Salaam, 2007.

US ICOMOS. Managing Change: Sustainable Approaches to the Conservation of the Built Environment. Philadelphia, 2001.

Warren John, John Worthington and Sue Taylor. Context: New Building in Historic Settings. Oxford: Architectural Press, 1998.

Yin, Robert K. Case Study Research, Design and Methods. London: SAGE, 1994. 